Www.ijbpas.com

\title{
TO STUDY OF ANTIBACTERIAL ACTIVITY OF LAWSONIA INERMIS LEAF EXTRACT
}

\section{KOMAL SURYAWANSHI", PUJA PUJARI, BALIRAM SARVADE, KRISHNA YADAV AND VISHAL GHADGE \\ Padmini College of Pharmacy, Dighanchi, Sangli, Maharashtra, 415315, India \\ *Corresponding Author: Komal Suryawanshi; E Mail: baliramsarvade7@gmail.com}

Received $9^{\text {th }}$ May 2021; Revised $10^{\text {th }}$ July 2021; Accepted 29 ${ }^{\text {th }}$ Aug. 2021; Available online $15^{\text {th }}$ Dec. 2021

\section{https://doi.org/10.31032/IJBPAS/2021/10.12.1042}

\begin{abstract}
Medical factory have veritably important place as they not only maintain the health and vitality of mortal beings and creatures. India is a largest patron of medicinal shops and correctly called the " Botanical Garden of the World " the factory Lawsonia inermis. L. Family - Lythraceae. Generally known as Henna or Mehandi is known as ornamental parcels. The effect of water and chloroform excerpt of the leaves of the Lawsonia inermis (Henna factory) against the primary raiders of burnt was delved. Clinical isolates of staphylococcus aureus, streptococcus sp, Pseudomonas Aeruginosa, candida albicans, Fusarium oxysporum and Asparagillus niger were treated with excerpt of leaves of L. inermis of antimicrobial exertion using invitro agar, objectification system and well prolixity system independently. The factory has been reported to have analgesic, antimalarial, hypoglycemic, hepatoprotective, antiinflammatory, antibacterial, antimicrobial, antifungal, antiviral, antiparasitic, antidermatophytic, antioxidant and antianthalmintic tuberculostatic and anticancer properties.

The review gives a view substantially on traditional uses, phytochemistry, pharmacological action of factory.
\end{abstract}

Keywords: Lawsonia inermis L . Traditional medicine anti-inflammatory enzyme inhibitor, phytochemistry, pharmacological action 


\section{INTRODUCTION}

Bacteria are microorganisms that beget complaint of some of cause fatal complaint in humans. Every time millions of people die because of these microorganisms. The adding of bacteria inside the mortal body takes advantages of any weakness plant in body organs. Plant has been to treat humans, creatures and factory complaint from old. Herbal drugs have been known to man for century.Henna factory Lawsonia inermislinn, is such a factory known for healing attributes and now the subject of violent scientific study. Though it was used for colorful purpose. The antifungal property wasn't yet delved. Therefore the present study was conducted to estimate its antifungal eventuality. Lawsonia inermis (Henna) is an cosmetic evergreen factory cultivated in the tropics. It belongs to family Lythraceae in sudan it's traditionally used to develop red and black colouring to hands, bases andhair. In some occasions similar as marriage and religious carnivals. Reverse - Egyptian privet, Lawsonia alba. Biological source Henna correspond of fresh or dried leaves of factory Lawsonia inermis Lam. Geographical source Hennais indigenous to Africa

and is largely cultivated in Egypt, sudan, carribean is let, Florida, India and China. It's annulled and cultivated in tropics of
America, Egypt, India, and part of Middle east.

Microscopic characters: -(1) Colour :Greenish brown (2) Odour:Characteristics (3) Taste:-Bitter and astringent.

Chemical constituents:- The active constituents of leaf is Lawsone (0.5-1.0) other constituent are 5-10\% gallic acid, white resin, sugar, and tanins and xanthones are other content of leaves. Lawsone the main colouring constituent said to be degradation product of primary glycosides hennosides A, B, and C .

Chemical test :- Extract from henna leaves with water by boiling and filter and cool. This decoction fades on addition of acid while depend by addition of alkali . Standards of quality :Moisture content :- Not more than 9\% . Ash content :- Not more than $15 \%$. Tannin content:- 10\% . Water soluble extracts :- 25-33\% . Uses:- Used as a favourite hair dye either alone or in combination for treatment of grey hair. It is used in several hair care product like rinses, conditioners, applications . Henna impart orange red colour which is more stable in acidic medium $(\mathrm{pH}$ 5.0 ). 
Lawsone the active constituent of leaves shown to have antibacterial and antifungal properties. Today we are witnessing a great deal of public interest in use of Herbal remedies. Further more many westernal drugs had been origin in plant extract. We are going to prepare the Gel of (Henna) Lawsonia inermis Lin, Used as an antifungal, antimicrobial, antibacterial, antiparasitic activity .

\section{MATERIALS AND METHODS}

Micro-organisms:- Five pathogenic bacteria due to disease caused by it are obtained from AL-hussein hospital and given numbers $1,2,3,4$ and 5 . This bacterias are pseudomonas aeruginosa, pseudomonas oryzihabita, proteusvaraplis, klebsiella pneumonia and staphyllococcus aureus.

\section{Extraction Process:-}

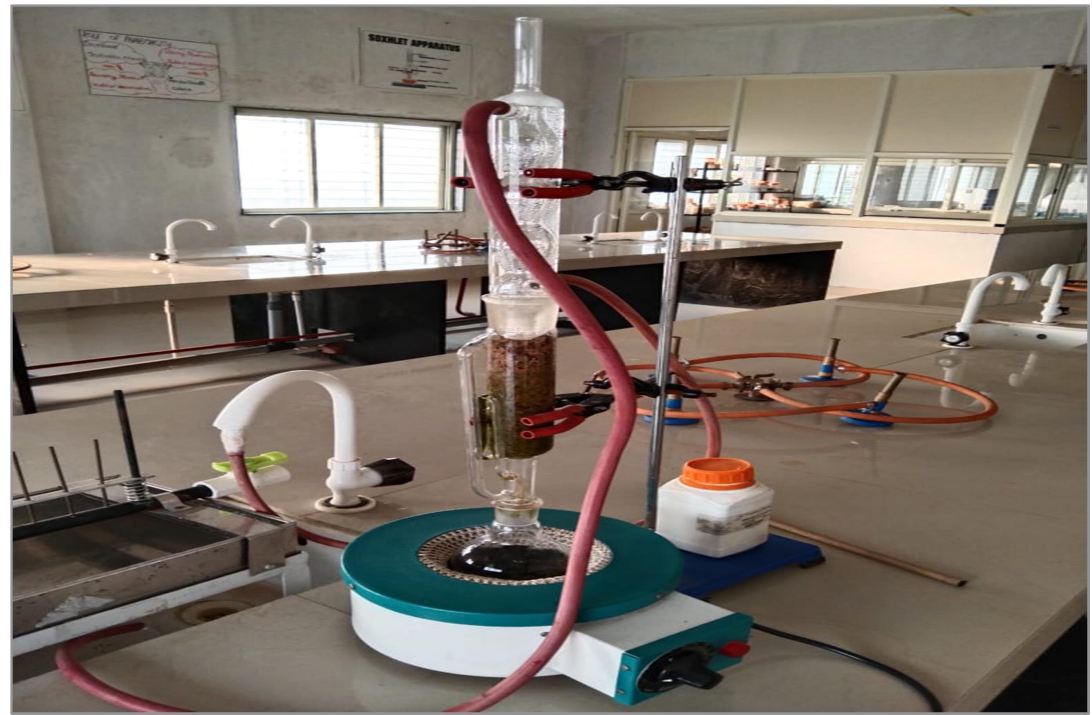

Figure 1

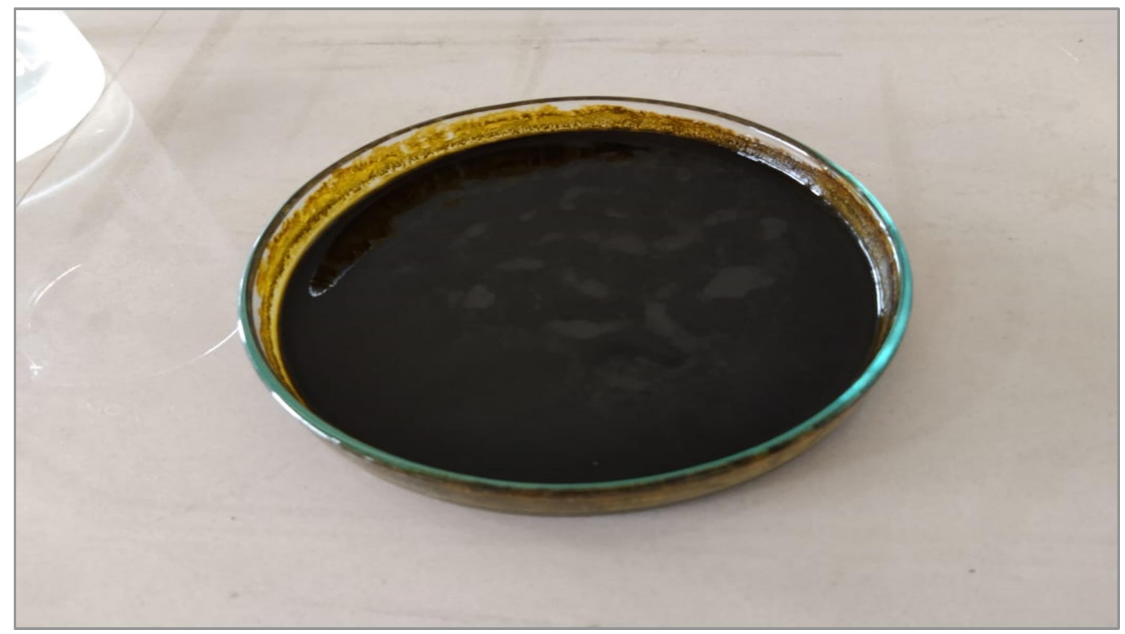

Figure 2 
Take dried leaves of (Henna) Lawsonia insermis

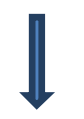

Fill the thimble of the soxhlet apparatus

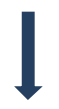

Add the solvent(ethanol-200ml)

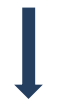

Set the assembly of this extraction

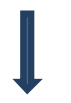

Keep this process of extraction continued till $48 \mathrm{hrs}$ at $60^{\circ} \mathrm{c}$

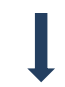

Complete the 6 to 7 cycles of this process

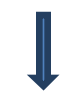

Collect the extract

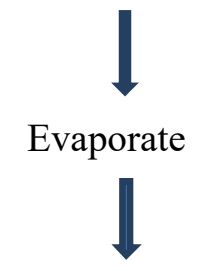

Semisolid mass was formed

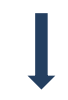

Use these semisolid or final extract as a active ingredient to prepare the gel of (Henna) Lawsonia inermis used as an antifungal, antibacterial.

\section{Determination of Best solvent:-}

Ethanol, Chloroform, Ethyl Acetate are the best solvents used for the extraction of (Henna) Lawsonia inermis.

\section{Method of preparation of Gel:-}




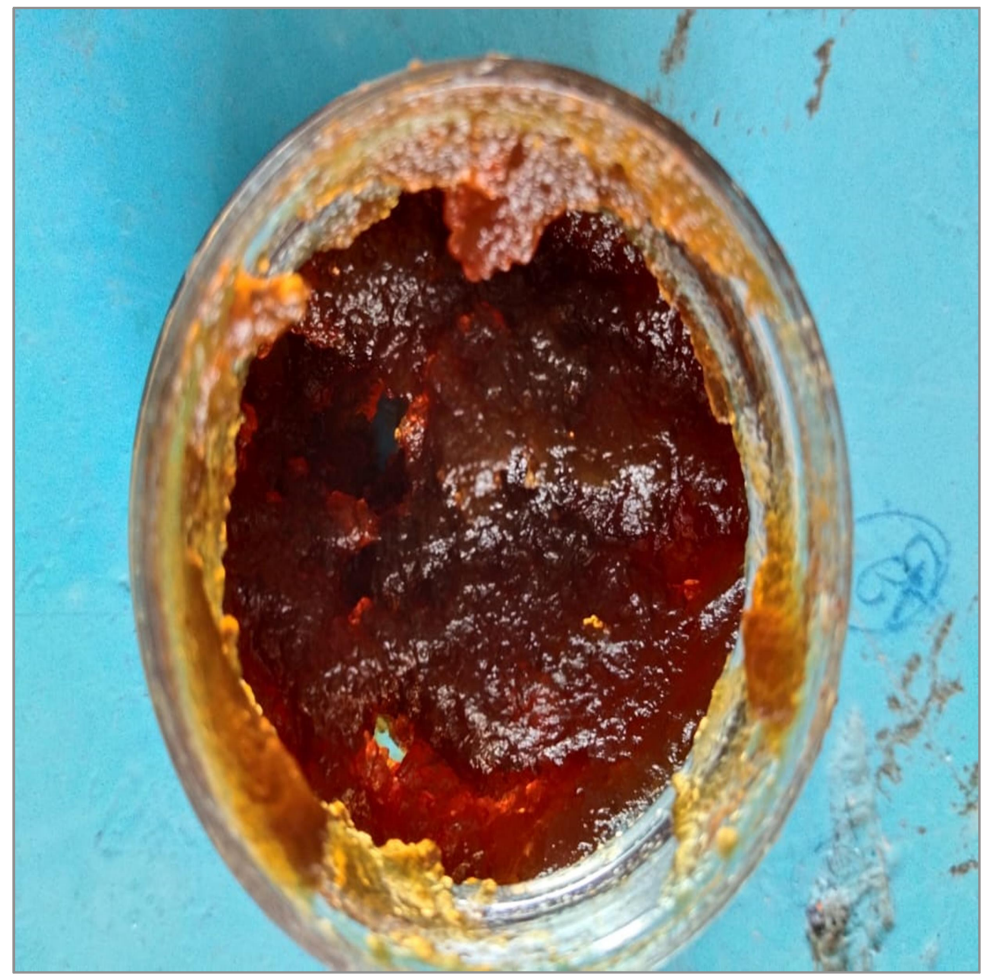

Figure 3

Take $5 \mathrm{ml}$ distilled water + Methyl paraben and Propyl paraben<smiles>C=CC=C</smiles>

Heating on water bath

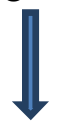

After the cooling add propylene glycol

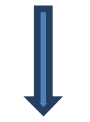

Then add different concentration of Heena extract<smiles>[AlH2]</smiles>

At last full mixed ingredients added in carbopol 934 gel with properly<smiles>C=CC</smiles>

Continuous stirring add tri-ethanolamine dropwise for adjust the $\mathrm{pH}(6.8-7)$ 


\section{Evaluation of Herbal Gel:-}

PH measurement:-

The $\mathrm{pH}$ conductivity of gel formulation where determined by using digital $\mathrm{pH}$ meter .The glass electrode was calibrated with the solutions determined for the equipment ( $\mathrm{pH}$ of 4.00 and 7.00$)$ and the conductivity measurement was done in millivolts $(\mathrm{mv})$. The preparation was left for about $15 \mathrm{~min}$ for attaining equilibrium while measuring. The analysis of $\mathrm{pH}$ and conductivity of formulation were done in triplicate and average values were calculated.

\section{Determination of viscosity:-}

Viscosities of the formulated gel were determined using Brookfield Viscometer. Spindle no. 7 and spindle speed $60 \mathrm{rpm}$ at 25 degree celsius were used for gels, corresponding dial reading on the viscometer was noted. Then the spindle was successively lowered. The dial reading was multiplied by factor given in the viscometer catalog.

Table 1: Tests

\begin{tabular}{|c|c|c|c|}
\hline Sr. no. & Components & Tests & Results \\
\hline 1. & Alkaloids & Wagners reagent & +++ \\
\hline 2. & Anthraquinones & Chloroform & +++ \\
\hline 3. & Flavonoids & Sodium hydroxide & ++ \\
\hline 4. & Phenols & Ferric chloride & ++ \\
\hline 5. & Saponins & Frothing & + \\
\hline 6. & Tanins & Sulphuric acid & +++ \\
\hline 7. & Triterpenes & Acetic anhydride & + \\
\hline 8. & Steroids & Fehlings solution & + \\
\hline 9. & Reducing sugar & 2,4-Dinitrophenylhydrazin & +++ \\
\hline 10. & Carbonyls & Hydrochloric acid & + \\
\hline
\end{tabular}

Key: $+=$ Low concentration, $++=$ Moderate concentration, $+++=$ High concentration

\section{RESULTS}

The current investigation showed that Henna plant possess good antimicrobial activity against tested fungi. The obtained result demonstrated antifungal activity of both extracts. The cup agar diffusion method revealed antifungal activity of extract against yeast and mould demonstrated by area of inhibition zone around the wells, while inhibition of growth revealed antifungal activity against dermatophytes. The ethanol extract has shown significant activity against yeast compared to petroleum ether extract. The inhibition zone induced by ethanol extract at concentration of $10 \mathrm{mg} / \mathrm{ml}$ was found to be $26.3+$ or - against saccharomyces cerviviae. The ethanol extract displayed fungicidal activity to tested moulds at a concentration of $5 \mathrm{mg} / \mathrm{ml}$ and fungistatic activity to Aspergillums flavour at a concentration of $10 \mathrm{mg} / \mathrm{ml}$. The result in below table show that percentage of substance using extraction are 14.94, 38.66, $2.5,1.75$, by using each of solvents. 
Table 1

\begin{tabular}{|c|c|c|c|c|}
\hline Sr. no. & Extraction solvent (100ml) & $\begin{array}{c}\text { Original weight of plant } \\
\text { powder }\end{array}$ & Weight of extract & $\begin{array}{c}\text { \% of extract } \\
\text { materials. }\end{array}$ \\
\hline 1. & Ethanol & $53.95 \mathrm{gm}$ & $\mathbf{2 0 . 8 6} \mathrm{gm}$ & $38.66 \%$ \\
\hline 2. & Chloroform & $42.55 \mathrm{gm}$ & $\mathbf{6 . 3 6} \mathrm{gm}$ & $\mathbf{1 4 . 9 4 \%}$ \\
\hline 3. & Ethyl acetate & $20 \mathrm{gm}$ & $\mathbf{0 . 5} \mathrm{gm}$ & $2.5 \%$ \\
\hline 4. & Distilled water & $20 \mathrm{gm}$ & $\mathbf{0 . 3 5} \mathrm{gm}$ & $1.75 \%$ \\
\hline
\end{tabular}

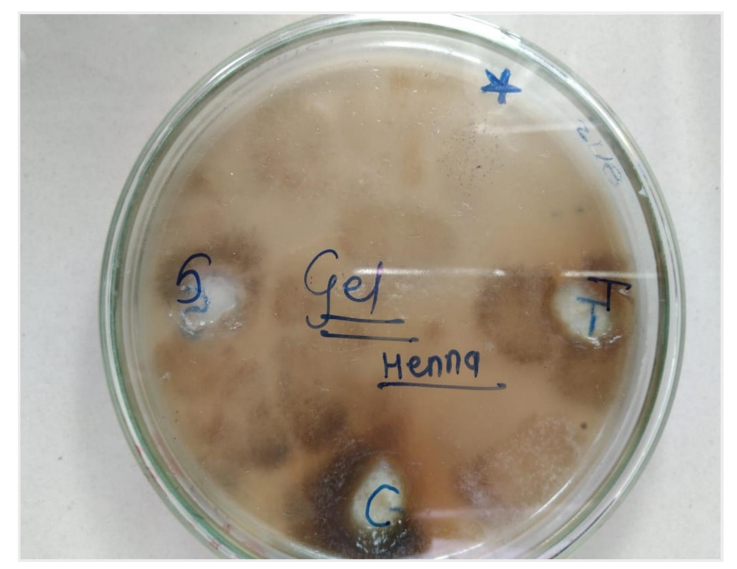

Figure 4

\section{DISCUSSION}

Lawsonia inermis leaves have antibacterial activity against many types of bacteria including staphylococcus aureus, klebsila pneumonia where ethanol is used as a solvent. In comparison with present study Lawsonia inermis leaves which consist of alkaloids, flavonoids, tanins, phenolics using Acetone $100 \%$ In our study we founf in result that the Lawsonia inermis leaves have minimum inhibitory concentration for staphylococcus aureus and klebsiella pneumonia is $11 \mathrm{mg} / \mathrm{ml}$ but in other study the minimum inhibition concentration for these bacteria is $25 \mathrm{mg} / \mathrm{ml}$ that mean our extract has more activity than that test and these contrast may be due to differences in solvent and differences in concentration of solvent Also the other research show that Lawsonia inermis leaves have antibacterial activity against Pseudomonas aeruginosa and Escherichia coli using ethanol as a solvent. Comparing this results with our results using Lawsonia inermis leaves with acetone $100 \%$ in our study and ethanolic extract in other research, we see that our extract has antibacterial activity against Pseudomonas aeruginosa in Mueller Hintone agar well diffusion test and diameter of inhibition zone is $17.33 \mathrm{~mm}$ but in other test the diameter of inhibition zone of Lawsonia inermis leaves with ethanol 
against Pseudomonas aeruginosa in $15 \mathrm{~mm}$ that mean our extract is more active than ethanolic extract and this is either due to less activity of their solvent than our solvent or due to the concentration of methanol that they have been used which is less activity.

\section{CONCLUSION}

From result of present study we can concluded that the extract of Lawsonia inermis leaves by acetone $100 \%$ has high antibacterial activity against the pathogenic bacteria that isolated from patients.

Recommendation:-Other study on Lawsonia inermis leaves is to purify the compound which owns the effectiveness of antibacterial pathogenesis.

\section{REFERENCES}

[1] Beukel DVD. Traditional Mehandi Designs a Treasury of Henna Body Art, Bostan Shambhala, 2000. ISBN 978-1570625589.

[2] AI -Daamy AAK, AI - Shibli MK, AI - Ghanimi AA. Purification and characterization of Kojic Acid Produced by two lacal isolates (Asperagillus flavus and Asperagillus fumigatus.) Thesis, College of Education, University of AI - Quadesiah, Iraq, 2014.

[3] E.Goun, G.Cunningham, D.chu, C. Nguyen and D. Miles, 'Antibacterial and Antifungal activity of
Indonesian ethnomedical plants', Fitoterapia, vol .74, no.6, pp.592$696,2003$.

[4] H.S. Muhammad and S. Muhammad. The use of Lawsonia inermis linn, (henna) in the management of burn wound ingection .African Journal of Biotechnology ,vol 4,no.9,pp. 934937,2005 .

[5] R.D. Tripathi, H. S. Srivastava, and S. N. Dixit. 'A Fungitoxic principle from leaves of Lawsonia inermis Linn. Exeperientia, vol,.34, no.1, pp.51-52,1978.

[6] J.B.Harborne, phytochemical Methods, vol.4, Chapman and Hall, 4, $2^{\text {nd }}$ edition 1984.

[7] F. Kavanah, Analytical Microbiology, vol II, Academic press, New York, NY, USA, 1972.

[8] F.Hadecek and H.Greger, 'Testing of Antifungal' on Natural product methodologies, comparability of result and assay choice, 'Journal of analytical phytochemistry, vol II, pp.137-141, 2000.

[9] M.obeidat, M. Shatnawi, M.Alalawi et al, 'Antimicrobial activity' of crude extract of some plant leaves. 'Research journal of Microbilogy' vol.7, no.1, pp. 59-67, 2012. 
[10] M. A. Abdulmoneium, 'Evaluation of Lawsonia inermis Linn'. (Sudanese Henna) leaf extract as an antimicrobial agent. 'Research journal of Biological Sciences, vol.2, pp.417-423, 2007.

[11] Chaudhary G, Goyal S, Poonia P. Lawsonia inermis Linnaeus. A phytopharmacological Review. Int J pharm sci and Drug Res 2010 2(2):91-8.

[12] Babu PD, Subhashree RS. Antimicrobial Activities of Lawsonia inermis- A Review. Acad J plant sci.2009;2(4):231-2.

[13] Ghosh A, Das BK, Roy A, Mandal B, Chandra G, Antibacterial activity of some medicinal plant extract J Nat Med 2008; 62(2) : 259-62.

[14] Munshi SR, shetye TA; Nair RK, Antifertility activity of three indigenous plant preparation. Planta Med 1977;31(1)73-5.

[15] Gupta A, Saifi AQ, Modi NT, Mishra N. Anti-inflammatory activity of some active principle of Lawsonia inermis leaves. Indian Journal of Pharmacology 1986; 18(2):133-4. 